Br Heart f 1980; 43: 607-8

\title{
Development of the membranous septum in the human heart
}

Sir,

I have read the interesting morphological work by Drs Allwork and Anderson (Br Heart $\mathcal{F}$ 1979; 41: 275-80) and congratulate them on it. As far as the manner of development of the two parts of the membranous septum is concerned, their results confirm my findings on the development of the Chiroptera heart, ${ }^{1}$ which have been quoted by Patten. ${ }^{2}$ As regards the human heart my conclusions were that "the two components (ie the interventricular and the atrioventricular) of the membranous septum in man-as in Chiroptera-have a single subendocardiac origin, in consequence of the formation of the septal leaf of the tricuspid valve and have no connection either with the bulbar septum or with the ventricular foramen". ${ }^{3}$

However, I disagree with the opinion of Drs Allwork and Anderson, concerning the time at which these two components of the membranous septum develop. I found, both in Chiroptera and human hearts, that the two parts of the membranous septum always develop before birth. ${ }^{13}$ In fact, in the human heart the myoendocardial undermining which moulds the septal leaf of the tricuspid valve begins in 30 to $47 \mathrm{~mm}$ long fetuses (approximately three months old). At 5 months the same septal leaf arises from the caudal margin of the membranous septum which is thus as yet wholly atrioventricular. Perhaps the small number of fetuses led the authors to miss later developmental ages which are enlightening. Unpublished observations show that in the hearts of 6-and 7-month-old fetuses the undermining goes on and the septal leaf at this age arises from the membranous septum dividing it into atrioventricular and interventricular parts. In the 8- and 9-month-old fetuses and in newborns both of the membranous parts grow thinner and become more dense. Therefore, contrary to Allwork and Anderson's opinion, these two parts are already distinct long before birth.

According to Savary ${ }^{4}$ (and in my experience) the relative sizes of the two components are inversely proportional to each other, with individual variations. Perhaps the variations in the level of insertion of the right septal leaf are connected with the mechanical effect of haemodynamics on the embryonal (and, therefore, easily undeterminable) connective tissue of the membranous septum. If this undermining stops at the caudal margin of the embryonal membranous septum this remains entirely atrioventricular (as in two of the seven adult Chiroptera hearts I examined ${ }^{1}$ ); if the undermining stops at the level of the embryonal membranous septum, this will show the two typical components; when the undermining concerns the whole embryonal membranous septum up to its cranial margin it will become entirely interventricular. These findings agree with Savary's reports that the membranous septum was wholly atrioventricular in 4 per cent, wholly interventricular in 10 per cent, and divided into atrioventricular and interventricular parts in 86 per cent of the adult human hearts examined.

$$
\begin{aligned}
& \text { G Conte, } \\
& \text { Istituto di Anatomia Umana } \\
& \text { Normale, dell’Università di } \\
& \text { Pisa, Pisa, Italy. }
\end{aligned}
$$

\section{References}

${ }^{1}$ Conte G, Arrigoni P. Sulla divisione dei ventricoli e del bulbo e sulle modalità di formazioni del setto membranaceo inter-atrio-ventricolare nei Chirotteri. Atti Soc Tosc Sc Nat 1966; B 73: 27-90.

${ }^{2}$ Patten BM. Human embryology, 3rd ed. New York, Toronto, Sydney, London: McGraw-Hill, 1968.

${ }^{3}$ Conte G, Arrigoni P. Contributo alla conoscenza dello sviluppo del setto membranaceo inter-atrio-ventricolare nell'uomo. Atti Soc It Anat XXV Conv Bari, 1966. In Arch Ital Anat Embriol, 1967; Suppl 72: abstract, p 43. ${ }^{4}$ Savary M. Beitrag zur Kenntnis des Septum membranaceum cordis. Untersuchung an 167 menschlichen Herzen. Acta Anat (Basel) 1964; 59: 333-60.

This letter was shown to Drs Allwork and Anderson who reply as follows:

Sir,

We read Dr Conte's comments with interest, especially his observations on the heart of the bat. However, it seems to us that it is probably inappropriate to interpret the findings in one species in the light of those in another disparate animal.

Dr Conte's finding that some fetal and neonatal hearts possess both components of the membranous septum, endorses rather than disagrees with our 
observations. In our series the majority of young hearts had only an atrioventricular membranous septum, but we noted and illustrated hearts with both (our Fig. 3a and b).

We agree with Dr Conte that the process whereby the membranous septum attains its adult morphology and size depends upon the emancipation of the medial tricuspid leaflet from the muscular septum. We illustrated the variable timing of this event in Fig. 2 and 3. Our Fig. 7 suggests that this "modelling" process may be lifelong, but we have reservations about attributing this or any other developmental process to haemodynamics.

S P Allwork, R H Anderson, Royal Postgraduate Medical School, Hammersmith Hospital, Ducane Road, London W12 0HS. 